\title{
Methotrexate shows the same efficacy and safety in the real world in all subtypes of JIA as in the controlled trial
}

\section{Foedvari* and A Wierk}

Address: Hamburger Zentrum fuer Kinder- und Jugendrheumatologie, Hamburg, Germany

* Corresponding author

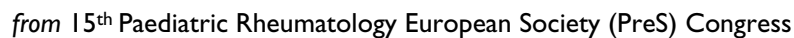

London, UK. 14-17 September 2008

Published: 15 September 2008

Pediatric Rheumatology 2008, 6(Suppl I):P65 doi:I0.I I86/I546-0096-6-SI-P65

This abstract is available from: http://www.ped-rheum.com/content/6/SI/P65

(c) 2008 Foedvari and Wierk; licensee BioMed Central Ltd.

\section{Background}

Methotrexate (MTX) is the mostly used second line agent to treat Juvenile idiopathic arthritis (JIA). This study presents a retrospective data evaluation.

\section{Objectives}

To prove the efficacy and safety of MTX in all subtypes of JIA in a retrospective cohort.

\section{Methods}

Single center open-label evaluation of the efficacy and safety of MTX treatment in patients with JIA where treatment was initiated between 31 st of March 2005 and 31 st of December 2007.

\section{Results}

105 patients were MTX initiated aged between 1 to 17 years. 61 of them were female $(58.1 \%)$. The mean treatment duration was 13.9 months. The mean MTX dose was $14.7 \mathrm{mg} / \mathrm{m} 2 /$ week. The response to therapy is shown in table 1, response occurred at months 3 and stayed stable over the observation period.

Adverse effects (AE) were reported by $41 \%$ of the patients, which were evenly distributed over the observation period. One severe AE occurred, one patient died with ALL.

\section{Discussion}

In this real world retrospective study of all JIA subsets MTX appears to be a safe and effective drug. 
Table I:

\begin{tabular}{lllll}
\hline & baseline & At 3 months & At 6 months & At I2 months \\
\hline CHAQ-pain subscale & 0.886 & 0.466 & 0.386 & 0.338 \\
CHAQ-disability subscale & 0.76 & 0.491 & 0.425 & 0.343 \\
CHAQ-severity subsccale & 0.398 & 0.248 & 0.184 & 0.207 \\
Number of swollen joints & 2.4 & 0.8 & 0.6 & 0.4 \\
Number of tender joints & 2.6 & 1.4 & 1.1 & 0.8 \\
Number of joints with LROM & 3.3 & 2.8 & 2.4 & 2.4 \\
Physician global (VAS) & 2.4 & 1.0 & 0.8 & 0.6 \\
Elevated CRP & $45.7 \%$ & $14.3 \%$ & $12.5 \%$ & $42.9 \%$ \\
Elevated Sedimentation rate & $43.8 \%$ & $17.5 \%$ & $21.1 \%$ & $42.1 \%$ \\
\hline
\end{tabular}

Publish with Biomed Central and every scientist can read your work free of charge

"BioMed Central will be the most significant development for disseminating the results of biomedical research in our lifetime." Sir Paul Nurse, Cancer Research UK

Your research papers will be:

- available free of charge to the entire biomedical community

- peer reviewed and published immediately upon acceptance

- cited in PubMed and archived on PubMed Central

- yours - you keep the copyright 